\section{Phosphate Diester Cleavage, DNA Interaction and Cytotoxic Activity of a Bimetallic Bis(1,4,7-triaza- cyclononane) Zinc Complex}

\author{
Diego Montagner, *[a] Valentina Gandin, ${ }^{[b]}$ Cristina Marzano, ${ }^{[b]}$ and \\ Andrea Erxleben*[a]
}

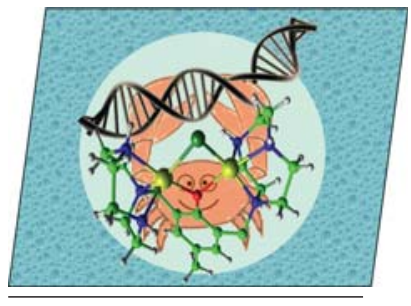

COVER PICTURE

Keywords: Drug design / Antitumor agents / Cytotoxicity / Zinc / DNA / DNA cleavage

The dinuclear zinc complex $\left[\mathrm{Zn}_{2}\{\mathrm{bcmp}(-\mathrm{H})\}(\mu-\mathrm{Cl})\right]\left(\mathrm{ClO}_{4}\right)_{2}$. $\mathrm{H}_{2} \mathrm{O} \quad\{\mathrm{bcmp}=2,6$-bis(1,4,7-triazacyclonon-1-ylmethyl)-4methylphenol\} has been synthesized and structurally characterized. The DNA binding affinity was assessed by ethidium bromide fluorescence quenching experiments. The complex relaxes supercoiled pUC19 DNA into the nicked form at low micromolar concentration. Mechanistic studies were carried out using the DNA and RNA models bis(2,4-dinitrophenyl) phosphate (BDNPP) and 2-hydroxypropyl p-nitrophenyl phosphate (HPNP). A detailed kinetic analysis suggested that the bridging $\mathrm{OH}$ group of the solution species $\left[\mathrm{Zn}_{2}\{\mathrm{bcmp}(-\mathrm{H})\}(\mu-\mathrm{OH})\right]^{2+}$ acts as the nucleophile in the hydrolysis of BDNPP, while in the case of HPNP, the bridging $\mathrm{OH}$ group acts as a general base and seems to shift to a terminal position upon substrate coordination. Finally, the cytotoxicity profile of the dinuclear zinc(II) complex was assessed. The complex showed promising in vitro antitumour activity against pancreatic and lung cancers cell lines.

\section{Introduction}

Despite the great success of platinum-based drugs in anticancer chemotherapy with cisplatin, oxaliplatin and carboplatin being in routine clinical use, ${ }^{[1]}$ severe side effects, a high general toxicity and inherent and acquired resistance are major limitations. ${ }^{[2]}$ Recently, complexes of endogenous transition metal ions such as $\mathrm{Cu}$ and $\mathrm{Zn}$ attract significant interest as potential new cancer therapeutic agents. ${ }^{[3]}$ However, despite the variety of physiological roles of the $\mathrm{Zn}^{2+}$ ion $^{[4]}$ and the wide repertoire of $\mathrm{Zn}^{\mathrm{II}}$ complexes as DNA binding agents, ${ }^{[5]}$ photosensitizers in tumour therapy, radioprotective, ${ }^{[6]}$ antidiabetic insulin-mimetic ${ }^{[7]}$ and antibacterial or antimicrobicial agents, ${ }^{[8]}$ very few data on the cytotoxicity of zinc-based compounds against human cancer cell lines have been reported. ${ }^{[9]}$

Zinc is an essential metal in most living organisms and it is found in the active site of many metalloenzymes. It plays an important role in biological hydrolysis reactions

[a] School of Chemistry, National University of Ireland, Galway, Ireland

E-mail: andrea.erxleben@nuigalway.ie diego.montagner@nuigalway.ie http://www.nuigalway.ie/chemistry/level2/staff/a_erxleben/ a_erxleben_res.html

[b] Dipartimento di Scienze del Farmaco, Università degli Studi di Padova,

Padova, Italy

Supporting information for this article is available on the WWW under http://dx.doi.org/10.1002/ejic.201402319. and examples of hydrolytically active zinc enzymes include P1 nuclease, ${ }^{[10]}$ alkaline phosphatase, ${ }^{[11]}$ phospholipase $C^{[12]}$ and aminopeptidase. ${ }^{[13]}$ The catalytic role of zinc in these enzymes includes Lewis acid activation of the substrate and the formation of $\mathrm{Zn}-\mathrm{OH}$ which can act as an efficient nucleophile or as a general base catalyst at physiological $\mathrm{pH}$. The high catalytic efficiency of dizinc enzymes has been attributed to the synergistic action of the two metal ions ${ }^{[14]}$ and has inspired the design and study of a large number of bimetallic Zn complexes as potential cleaving agents for nucleic acids and phosphate esters as their models. ${ }^{[15-17]}$ In particular, dinuclear zinc complexes with bis(1,4,7-triazacyclonon-1-yl) ligands [bis(tacn)] are of considerable interest due to their often remarkable reactivity towards phosphodiesters. A range of ligands with the two aza-crown rings separated by spacers of different length, rigidity and geometry have been studied to date. ${ }^{[18-21]}$ The dinuclear zinc complex of 1,3-bis(1,4,7-triazacyclonon-1yl)-2-hydroxypropane reported by Morrow et al. is one of the best dinuclear catalysts for the transesterification of the RNA model compound 2-hydroxypropyl p-nitrophenyl phosphate (HPNP). ${ }^{[22]}$ Scrimin et al. attached two tacn units to a heptapeptide. Upon addition of $\mathrm{Zn}^{2+}$ plasmid DNA was cleaved with a rate constant of $1.0 \times 10^{-5} \mathrm{~s}^{-1}$ under physiological conditions. ${ }^{[23 a]}$ Very recently, the same group attached $\mathrm{Zn}$ tacn moieties to the surface of gold nanoparticles to obtain a nanosystem that provides the 
highest $k_{\text {cat }}$ value for the cleavage of HPNP ever reported in water. ${ }^{[23 \mathrm{~b}]}$

Here we report the dinuclear zinc complex of the bis(tacn) ligand 2,6-bis(1,4,7-triazacyclonon-1-ylmethyl)-4methylphenol (bcmp), its interaction with DNA, bis(2,4-dinitrophenyl) phosphate (BDNPP) and HPNP as well as its cytotoxicity towards a panel of human tumour cell lines.

\section{Results and Discussion}

\section{Ligand Design and Synthesis}

It is well established that $\mathrm{Zn}^{2+}$ ions bind with unusually high affinity to ligands containing the nine-membered azacrown binding site 1,4,7-triazacyclononane. The $\log K$ value for mononuclear $\mathrm{Zn}(\operatorname{tacn})^{2+}$ is $11.3,{ }^{[24]}$ suggesting that the bis(tacn) ligand bcmp can form a highly stable $\mathrm{Zn}$ complex under physiological conditions. The aromatic spacer provides a rigid scaffold for the bimetallic site, while the bridging phenoxy group shields the electrostatic repulsion between the metal ions and holds the two $\mathrm{Zn}^{2+}$ ions in close proximity.

Bcmp (4) that has been previously reported ${ }^{[25]}$ was synthesized as depicted in Scheme 1. In contrast to the literature procedure, Boc was used to protect two of the three secondary amine nitrogens of tacn. This route was chosen over the original procedure using tosyl protecting groups because of the less time-consuming work-up and fewer purification steps required. The protected ligand 3 was synthesized by reacting 2,6-bis(chloromethyl)-4-methylphenol with two equivalents of tacn-(Boc $)_{2}(2)$. Deprotection of the amine with trifluoroacetic acid afforded $\mathbf{4}$ as a yellow oil which is soluble in methanol and water at alkaline $\mathrm{pH}$.

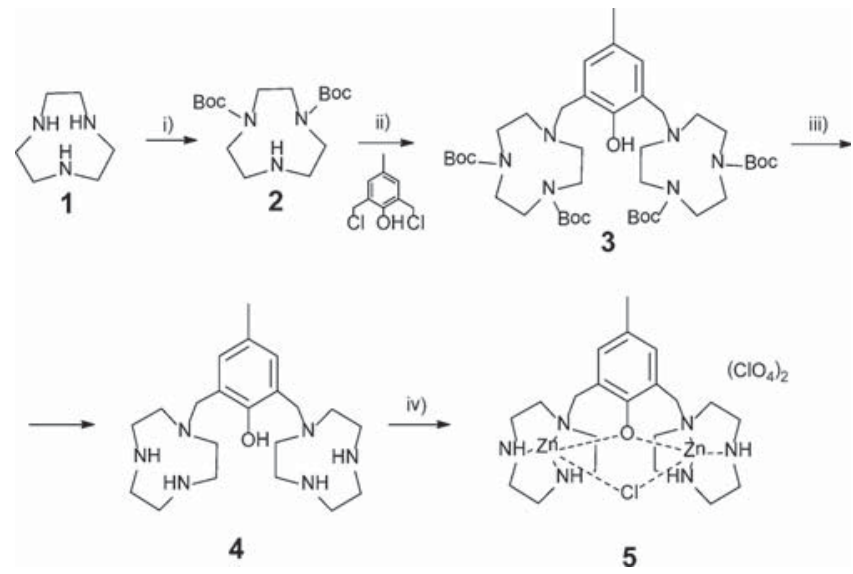

Scheme 1. Synthetic route for the synthesis of the $\mathrm{Zn}$ complex. i) BOC-ON, $\mathrm{CHCl}_{3}$; ii) $\mathrm{THF} / \mathrm{CHCl}_{3}$; iii) $\mathrm{TFA} / \mathrm{CH}_{2} \mathrm{Cl}_{2} / \mathrm{Et}_{2} \mathrm{O}$; iv) $\mathrm{Zn}\left(\mathrm{ClO}_{4}\right)_{2}$.

\section{Synthesis and Characterization of the Dizinc Complex}

The dinuclear zinc complex $\left[\mathrm{Zn}_{2}\{\mathrm{bcmp}(-\mathrm{H})\}(\mu-\mathrm{Cl})\right]-$ $\left(\mathrm{ClO}_{4}\right)_{2}(5)$ was prepared by reacting 4 with two equivalents zinc salt in methanol/water at $\mathrm{pH}$ 6-7. X-ray suitable crys- tals of $\mathbf{5} \cdot \mathbf{H}_{2} \mathbf{O}$ were obtained by slow evaporation of an aqueous solution of $\mathbf{5}$.

The X-ray structure of $\mathbf{5} \cdot \mathbf{H}_{\mathbf{2}} \mathbf{O}$ is shown in Figure 1, selected bond lengths and angles are listed in Table 1. The asymmetric unit of $\mathbf{5} \cdot \mathbf{H}_{\mathbf{2}} \mathbf{O}$ contains the complex cation with a bridging chlorido ligand, two perchlorate anions and one water molecule of crystallization. Each $\mathrm{Zn}$ centre adopts a distorted square-pyramidal coordination geometry with the tertiary nitrogen, one secondary amine nitrogen, the bridging chloride and phenolate oxygen defining the basal plane, while the apical site is occupied by the other secondary amine nitrogen. The $\tau$ value which indicates the degree of trigonal distortion from an ideal square-pyramidal coordination geometry is 0.269 for $\mathrm{Zn}(1)$ and 0.114 for for $\mathrm{Zn}(2)$. According to the definition by Addison $[\tau=(\alpha-\beta) / 60$ where $\alpha$ and $\beta$ are the two largest bond angles] an ideal square pyramid has a $\tau$ value of 0 , while $\tau$ is 1 for a trigonal bipyramid. ${ }^{[26]}$ The $\mathrm{Zn}$ ions are displaced by $0.416(1)$ [ $\left.\mathrm{Zn}(1)\right]$ and $0.280(1) \AA[\mathrm{Zn}(2)]$ from the basal plane in the direction of the apical nitrogen. The two apical nitrogens are anti to each other. The bridging phenolate oxygen and chlorido ligand hold the two $\mathrm{Zn}$ ions at a distance of 3.219(1) $\AA$, the $\mathrm{Zn}-\mathrm{O}_{\text {phenolate }}-\mathrm{Zn}$ and $\mathrm{Zn}-\mathrm{Cl}-\mathrm{Zn}$ angles are 107.2(1) and $85.65(3)^{\circ}$, respectively. The $\mathrm{Zn}_{2} \mathrm{OCl}$ unit in $\mathbf{5} \cdot \mathbf{H}_{\mathbf{2}} \mathrm{O}$ is essentially planar [maximum deviation from the best weighted plane 0.0147(9) $\AA$ for $\mathrm{O}(1)$ ]. The dihedral angle between the

(a)

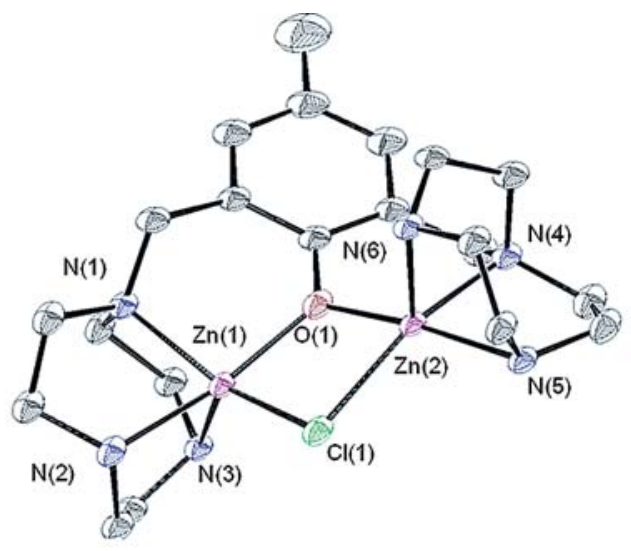

(b)

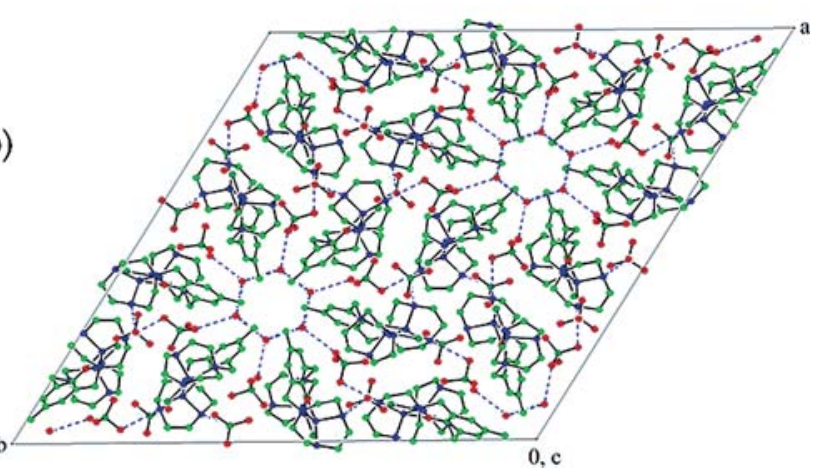

Figure 1. (a) View of the cation of $\left[\mathrm{Zn}_{2}\{\mathrm{bcmp}(-\mathrm{H})\}(\mu-\mathrm{Cl})\right]\left(\mathrm{ClO}_{4}\right)_{2}$. $\mathrm{H}_{2} \mathrm{O}\left(\mathbf{5} \cdot \mathbf{H}_{2} \mathrm{O}\right)$ with the atom numbering scheme. Thermal ellipsoids are drawn at the $40 \%$ level. (b) Crystal packing of $\mathbf{5} \cdot \mathbf{H}_{\mathbf{2}} \mathbf{O}$. Hydrogen atoms have been omitted for clarity. 
$\mathrm{Zn}_{2} \mathrm{OCl}$ plane and the bridging phenyl ring is $36.4(1)^{\circ}$. An interesting feature of the crystal structure of $\mathbf{5} \cdot \mathbf{H}_{2} \mathbf{O}$ is the packing of the complex cations and water molecules of crystallization in the crystal lattice (Figure 1, b). The complex cations are located around threefold screw axes with the methyl groups pointing inwards while hydrogen-bonding interactions between the water molecules generate hexagonal water clusters. In addition to donating a $\mathrm{H}$ bond to a neighbouring water molecule, each water acts as a $\mathrm{H}$ bond donor to a perchlorate oxygen so that each hexagon of water molecules is surrounded by six perchlorate anions. Further hydrogen bonding within the lattice is observed between amine nitrogens and perchlorate oxygens. Geometric parameters of the $\mathrm{H}$ bonding interactions in $\mathbf{5} \cdot \mathbf{H}_{2} \mathrm{O}$ are given in Table 1.

Table 1 . Selected bond lengths $[\AA]$, angles $\left[^{\circ}\right]$ and hydrogen bonding interactions in compound $\mathbf{5} \cdot \mathbf{H}_{\mathbf{2}} \mathbf{O}$.

\begin{tabular}{|c|c|c|c|}
\hline $\mathrm{Zn1-N1}$ & $2.099(3)$ & $\mathrm{Zn} 2-\mathrm{N} 4$ & $2.116(3)$ \\
\hline $\mathrm{Zn} 1-\mathrm{N} 2$ & $2.131(3)$ & $\mathrm{Zn} 2-\mathrm{N} 5$ & $2.088(3)$ \\
\hline $\mathrm{Zn} 1-\mathrm{N} 3$ & $2.065(3)$ & $\mathrm{Zn} 2-\mathrm{N} 6$ & $2.082(3)$ \\
\hline $\mathrm{Zn} 1-\mathrm{O} 1$ & $2.011(2)$ & $\mathrm{Zn2-O1}$ & $1.988(2)$ \\
\hline $\mathrm{Zn1-Cl1}$ & $2.3472(9)$ & $\mathrm{Zn} 2-\mathrm{Cl} 1$ & $2.3883(9)$ \\
\hline $\mathrm{Zn} 1 \cdots \mathrm{Zn} 2$ & $3.219(1)$ & & \\
\hline $\mathrm{N} 1-\mathrm{Zn} 1-\mathrm{N} 2$ & $83.41(11)$ & N4-Zn2-N5 & $84.09(12)$ \\
\hline $\mathrm{N} 1-\mathrm{Zn} 1-\mathrm{N} 3$ & $86.49(11)$ & N4-Zn2-N6 & $85.49(11)$ \\
\hline $\mathrm{N} 2-\mathrm{Zn} 1-\mathrm{N} 3$ & $84.27(12)$ & N5-Zn2-N6 & $85.39(11)$ \\
\hline N1-Zn1-Cl1 & $149.70(8)$ & N4-Zn2-Cl1 & 161.61(8) \\
\hline N2-Zn1-O1 & $165.85(11)$ & N5-Zn2-O1 & $168.47(11)$ \\
\hline $\mathrm{Zn} 1-\mathrm{Cl1}-\mathrm{Zn} 2$ & $85.65(3)$ & $\mathrm{Zn} 1-\mathrm{O} 1-\mathrm{Zn} 2$ & $107.21(10)$ \\
\hline \multicolumn{4}{|c|}{ Hydrogen-bonding interactions } \\
\hline $\mathrm{D}-\mathrm{H} \cdots \mathrm{A}^{[\mathrm{a}]}$ & $d(\mathrm{D} \cdots \mathrm{A})$ & $\angle$ (DHA) & \\
\hline $\mathrm{N} 2-\mathrm{H} 2 \mathrm{~N} \cdots \mathrm{O} 3^{\# 1}$ & $3.292(5)$ & 152 & \\
\hline $\mathrm{N} 2-\mathrm{H} 2 \mathrm{~N} \cdots \mathrm{O} 5^{\# 1}$ & $3.091(6)$ & 130 & \\
\hline 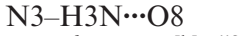 & $2.944(5)$ & 163 & \\
\hline $\mathrm{O}_{1} \mathrm{~W}^{b} \cdots \mathrm{O} 1 \mathrm{~W}^{[\mathrm{b}]}, \# 2$ & $2.84(1)$ & & \\
\hline $\mathrm{O}_{1} \mathrm{~W}^{b} \cdots \mathrm{O} 4^{\# 1}$ & $3.18(2)$ & & \\
\hline $\mathrm{O} 1 \mathrm{~W}^{b} \cdots \mathrm{O} 1 \mathrm{~W}^{[\mathrm{b}], \# 1}$ & $2.87(1)$ & & \\
\hline $\mathrm{O} 1 \mathrm{~W}^{b} \cdots \mathrm{O} 4^{\# 2}$ & $2.97(1)$ & & \\
\hline
\end{tabular}

[a] Symmetry operation: \#1: $-x+y, 1-x, z$; \#2: $y-1, y-x$, $1-z$. [b] Site occupancy 0.5 (cf. experimental section).

The stability of the dinuclear $\mathrm{Zn}$ complex in aqueous solution has been investigated by ${ }^{1} \mathrm{H}$ NMR spectroscopy (Figure $\mathrm{S} 1$ in the Supporting Information). The $\mathrm{CH}_{2}$ protons of the tacn rings that give a triplet around $2.7 \mathrm{ppm}$ in the free ligand $\left(\mathrm{D}_{2} \mathrm{O}, \mathrm{pD} 11\right)$ split into three broadened signals at $\delta=2.89,2.60$ and $2.50 \mathrm{ppm}$. No changes in the ${ }^{1} \mathrm{H}$ NMR spectrum are observed between pD 3.6 and 11.0 indicating that the $\mathrm{Zn}$ ions remain bound to the ligand over this $\mathrm{pD}$ range. At $\mathrm{pD}<3.6$ the ${ }^{1} \mathrm{H}$ NMR spectrum becomes more complicated and new resonances appear in the region of the ring methylene protons suggesting partial dissociation and formation of the mononuclear $\mathrm{Zn}$ complex.

Due to the lability of the $\mathrm{Zn}-\mathrm{Cl}$ bond, the spontaneous substitution of (bridging) chlorido ligands by water in aqueous solution is well established for zinc complexes ${ }^{[27-30]}$ and the species $\left[\mathrm{Zn}_{2}\{\mathrm{bcmp}(-\mathrm{H})\}(\mathrm{OH})\left(\mathrm{ClO}_{4}\right)\right]^{+}$was identified in the ESI MS spectrum of 5 in water (signal centred at $\mathrm{m} / \mathrm{z}$
= 637.11; Figure S2 in the Supporting Information). The potentiometric titration of the $\mathrm{Zn}$ complex revealed a single deprotonation step with a $\mathrm{p} K_{\mathrm{a}}$ value of $5.37 \pm 0.15$ (Figure $\mathrm{S} 3$ in the Supporting Information). Although clearly at the low end of the $\mathrm{p} K_{\mathrm{a}}$ range for a water molecule bridging two $\mathrm{Zn}$ ions, ${ }^{[31-33]}$ this value can be assigned to the formation of the hydroxo-bridged dizinc species.

$\left[\mathrm{Zn}_{2}\{\mathrm{bcmp}(-\mathrm{H})\}\left(\mu-\mathrm{H}_{2} \mathrm{O}\right)\right]^{3+}+\mathrm{OH}^{-} \rightleftarrows\left[\mathrm{Zn}_{2}\{\mathrm{bcmp}(-\mathrm{H})\}(\mu-\mathrm{OH})\right]^{2+}+$ $\mathrm{H}_{2} \mathrm{O}$

Relatively low $\mathrm{p} K_{\mathrm{a}}$ values for the formation of hydroxobridged metal complexes that indicate strong binding of the hydroxide ion to the metal ions are not unprecedented. For example, a $\mathrm{p} K_{\mathrm{a}}$ of 4.4 has been reported for the bridging water in the dinuclear nickel complex $\left[\mathrm{Ni}_{2}\left(\mathrm{H}_{2} \mathrm{O}\right)_{4}(\mathrm{bdpz})\right]^{4+}$ $\left\{\mathrm{bdpz}=1,4\right.$-bis $\left(2,2^{\prime}\right.$-dipyridyl-methyl $)$ phthalazine $\} .{ }^{[34]}$

\section{DNA Interaction}

The ability of the zinc complex to bind to CT-DNA was studied by evaluating the fluorescence emission intensity of the ethidium bromide (EB)-DNA system upon the addition of different amounts of the dinuclear $\mathrm{Zn}^{\mathrm{II}}$ compound. ${ }^{[35]}$ The fluorescence intensity of EB-DNA decreases rapidly with increasing concentrations of the complex. Results depicted in Figure 2 underlined that the dinuclear $\mathrm{Zn}^{\mathrm{II}}$ complex efficiently quenched the fluorescence emission of EB. Notably, the fluorescence quenching constant evaluated using the Stern-Volmer equation was 0.91 (cf. experimental section), thus indicating that the complex strongly binds to DNA. A DNA-binding metal complex can quench the EB emission by either competing with EB for binding sites or by accepting the excited state photon. It is unlikely that the $\mathrm{Zn}$ complex can compete with EB for intercalative binding sites and groove binding seems more likely.

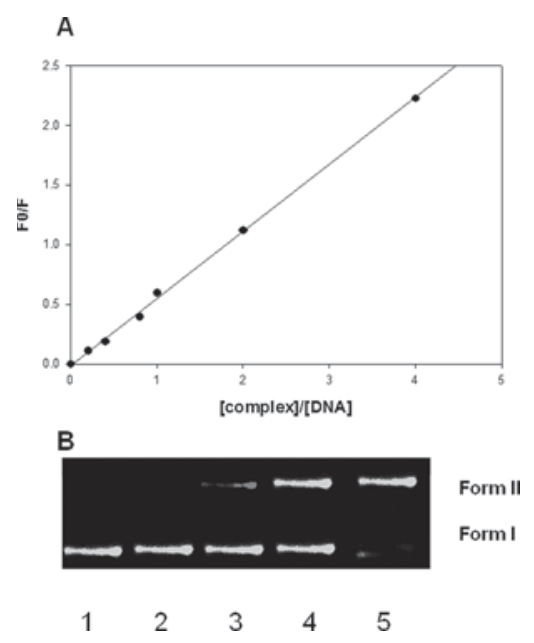

Figure 2. DNA binding and cleavage. A. Stern-Volmer quenching plot of $\left[\mathrm{Zn}_{2}\{\mathrm{bcmp}(-\mathrm{H})\}(\mu-\mathrm{Cl})\right]\left(\mathrm{ClO}_{4}\right)_{2}$. B. Agarose gel electrophoresis patterns of SC pUC19 DNA incubated with complex $\mathbf{5}$ in Tris buffer at $37^{\circ} \mathrm{C}$ for $3 \mathrm{~h}$. Lane 1, DNA control; lane 2, DNA $+\mathbf{5}$ $(5 \mu \mathrm{M})$; lane 3 , DNA + $5(10 \mu \mathrm{M})$; lane 4, DNA + $5(25 \mu \mathrm{M})$; lane $5, \mathrm{DNA}+\mathbf{5}(50 \mu \mathrm{M})$. 
The cleavage ability of the dinuclear $\mathrm{Zn}^{\mathrm{II}}$ complex was measured from the conversion of the SC form (form I) of plasmid pUC19 DNA to the nicked-circular form (NC, form II). SC pUC19 DNA (1 $\mu \mathrm{g} / \mathrm{mL})$ was incubated with increasing complex concentrations (range 5-50 $\mu \mathrm{M}$ ) for $3 \mathrm{~h}$. As depicted in Figure 2 (b), treatment with the dinuclear $\mathrm{Zn}^{\mathrm{II}}$ complex resulted in a concentration dependent cleavage of DNA. Interestingly, the bimetallic compound was able to convert SC-DNA into the NC form even at $10 \mu \mathrm{M}$ concentration (lane 3), and complete DNA cleavage (absence of the SC conformation) occurred at $50 \mu \mathrm{M}$ (lane 5).

\section{Phosphate Diester Hydrolysis}

In order to identify the catalytically active species that hydrolyses the phosphate diester linkages in DNA, kinetic experiments have been carried out with the activated substrate bis(2,4-dinitrophenyl) phosphate (BDNPP). The 5mediated cleavage of the activated RNA model compound 2-hydroxypropyl-4-nitrophenyl phosphate (HPNP) was also studied. The hydrolysis reactions were monitored by following the increase in the visible absorbance at $400 \mathrm{~nm}$ because of the release of 2,4-dinitrophenolate and 4-nitrophenolate, respectively.

\section{BDNPP Hydrolysis}

The dependence of the reaction rate of BDNPP cleavage on the $\mathrm{pH}$ value in the presence of $\mathbf{5}$ was studied over the $\mathrm{pH}$ range 3.5-9.5. The plot of the pseudo-first-order rate constants vs. $\mathrm{pH}$ revealed a sigmoidal curve (see Figures 3 and S4). A non-linear least-squares fit of the data gave a kinetic $\mathrm{p} K_{\mathrm{a}}$ value of $5.4 \pm 0.1$.

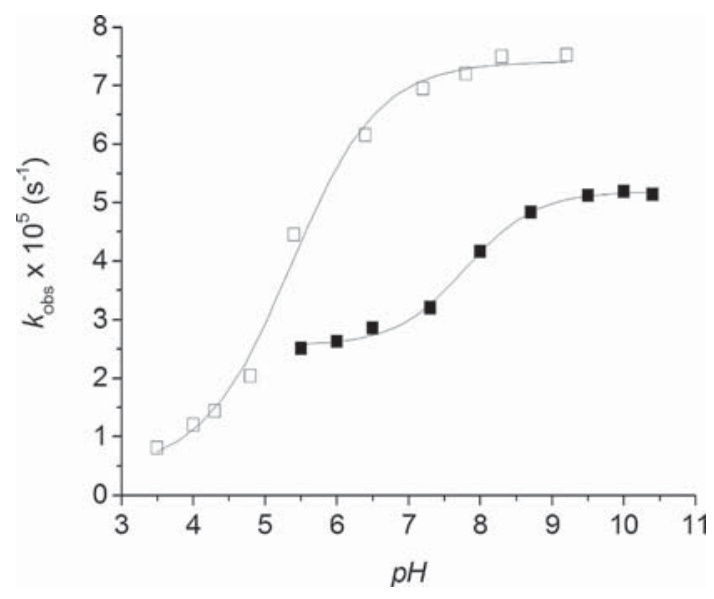

Figure 3. Rate-pH profile for the cleavage of BDNPP $\left(5 \times 10^{-5} \mathrm{M}\right.$; $\square)$ and HPNP $\left(5 \times 10^{-5} \mathrm{M} ; \mathbf{\square}\right)$ in the presence of $5(1 \mathrm{~mm})$ at $40{ }^{\circ} \mathrm{C}$. [buffer] = $50 \mathrm{~mm}[$ buffer $=$ PIPBS $(\mathrm{pH} 3.5-5), \operatorname{MES}(\mathrm{pH}$ 5-6.7), HEPES (pH 6.8-8.5), and CHES (pH 8.5-11.0)]; $I=0.1 \mathrm{M}\left(\mathrm{KNO}_{3}\right)$.

Figure 4 shows the dependence of the hydrolysis rate on the concentration of the zinc complex $\left(\mathrm{pH} \mathrm{8.0,40}{ }^{\circ} \mathrm{C}\right)$. At low concentration the rate constant increases linearly, while at concentrations $\geq 3 \mathrm{~mm}$ a gradual deviation from linearity is apparent. A linear fit of the data in the $0.25-3 \mathrm{~mm}$ range gave an apparent second-order rate constant of $0.028 \mathrm{M} \mathrm{s}^{-1}$ for low metal complex concentrations. The fact that the curve tends to flatten at higher concentration suggests weak binding between BDNPP and $\mathbf{5}$.

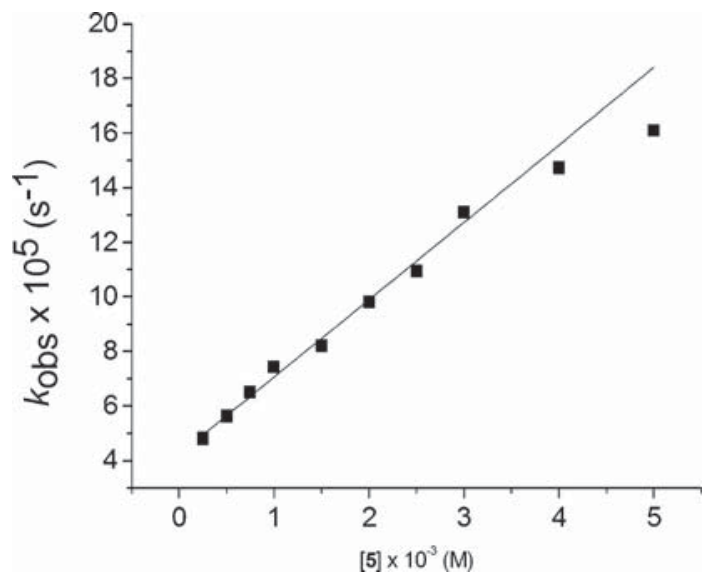

Figure 4. Dependence of the cleavage rate of BDNPP $\left(5 \times 10^{-5} \mathrm{M}\right)$ on the concentration of 5 at $\mathrm{pH} 8.0\left(50 \mathrm{~mm}\right.$ HEPES) and $40{ }^{\circ} \mathrm{C}$. I $=0.1 \mathrm{~m}\left(\mathrm{KNO}_{3}\right)$. The solid line shows the linear fit of the data using the first 8 data points.

The kinetic $\mathrm{p} K_{\mathrm{a}}$ value obtained from the rate-pH profile of 5-mediated BDNPP hydrolysis is in good agreement with the thermodynamic $\mathrm{p} K_{\mathrm{a}}$ value (5.37) and suggests that the bridging hydroxide acts as the reactive species, either as a nucleophile or a general base. To gain more insight into the reaction mechanism, the solvent deuterium isotope effect $k_{\mathrm{H}} / k_{\mathrm{D}}$ was measured. The solvent deuterium isotope effect is the classical method for distinguishing between a nucleophilic and a general base mechanism. Generally, a $k_{\mathrm{H}} / k_{\mathrm{D}}$ value ranging from 0.8 to 1.5 indicates a nucleophilic mechanism for phosphate ester hydrolysis, where no proton transfer is involved in the rate-determining step, while a $k_{\mathrm{H}} /$ $k_{\mathrm{D}}$ value greater than 2 supports a general base mechanism, where $\mathrm{M}-\mathrm{OH}$ deprotonates an external nucleophile. ${ }^{[38]}$ The average $k_{\mathrm{H}} / k_{\mathrm{D}}$ value obtained at different $\mathrm{pL}$ values $(\mathrm{L}=$ $\mathrm{H}, \mathrm{D})$ for the hydrolysis of BDNPP in the presence of $\mathbf{5}$ is 1.29 (Figure S5 and Table S1) suggesting a direct nucleophilic attack of the bridging $\mathrm{OH}$ group to the phosphorus. This mechanism is not unprecedented for dizinc complexes. ${ }^{[36,37]}$ By contrast, the hydrolysis of BDNPP complexes of type $\mathrm{Fe}^{\mathrm{III}}(\mu-\mathrm{OH}) \mathrm{M}^{\mathrm{II}}$ and $\mathrm{Fe}^{\mathrm{III}}\left(\mu-\mathrm{CH}_{3} \mathrm{COO}\right)_{2} \mathrm{M}^{\mathrm{II}}$ $(\mathrm{M}=\mathrm{Zn}, \mathrm{Cu}, \mathrm{Mn}, \mathrm{Fe})$ that have been extensively studied by Neves, Schenk and co-workers proceeds via a mechanism that involves monodentate coordination to the divalent metal ion followed by intramolecular attack of a terminally $\mathrm{Fe}^{\mathrm{III}}$-bound hydroxide. ${ }^{[39-42]}$ It was concluded that the $\mu-\mathrm{OH}$ was a poorer nucleophile than the terminal $\mathrm{OH}$. BDNPP hydrolysis by a dinuclear $\mathrm{Cu}^{\mathrm{II}}(\mu-\mathrm{OH}) \mathrm{Cu}^{\mathrm{II}}$ complex of a Schiff base ligand related to bcmp, 6-amino-6-methylperhydro-1,4-diazepine (AAZ), has recently been studied. ${ }^{[43,44]}$ DFT calculations on the complex-BDNPP adduct supported a reaction mechanism in which the bridging hydroxide acts as the nucleophile towards the phosphorus of the monodentally coordinated BDNPP as suggested for 5. 


\section{HPNP Cleavage}

As shown in Scheme 2, the uncatalyzed cleavage of RNA and HPNP proceeds via the intramolecular nucleophilic attack by the C-2 hydroxy group resulting in the formation of the 2,3-cyclic phosphate diester. ${ }^{[45]}$

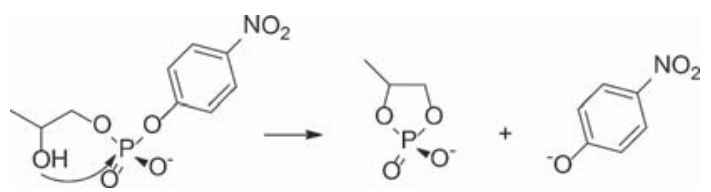

Scheme 2. Transesterification of HPNP following intramolecular nucleophilic attack.

The rate-pH profile of the 5-mediated cleavage of HPNP is depicted in Figures 3 and S6. Again, a sigmoidal curve was obtained. However, fitting the data gave a kinetic $\mathrm{p} K_{\mathrm{a}}$ value of $\mathrm{pH} 7.8 \pm 0.1$ which indicates that the active species for cleaving HPNP is different from that in BDNPP hydrolysis (see discussion below). The plot of the initial rate $\mathrm{v}_{0} \mathrm{vs}$. complex concentration (Figure 5) revealed saturation kinetics and the linear Lineweaver-Burk plot (Figure S7) indicated Michaelis-Menten behaviour with the formation of a kinetically active complex-substrate intermediate. From the Lineweaver-Burk plot, the hydrolysis rate of the bound substrate, $k_{\text {cat }}=2.60 \times 10^{-4} \mathrm{~s}^{-1}$, and the substrate binding constant, $1 / K_{\mathrm{m}}=206 \mathrm{M}^{-1}$, were obtained. These values indicate a good catalytic activity in comparison with other dinuclear $\mathrm{Zn}$ complexes ${ }^{[46-48]}$ and a moderate binding affinity of HPNP for $\mathbf{5}$. However, $\mathbf{5}$ is approximately 2 and 3 orders of magnitude less reactive than the two most efficient $\mathrm{Zn}$ catalysts reported by Mareque-Rivas and Williams ( $k_{\text {cat }}=$ $\left.0.017 \mathrm{~s}^{-1} ; \mathrm{pH} 7.4,25^{\circ} \mathrm{C}\right)$ and Scrimin et al. $\left(k_{\mathrm{cat}}=0.196 \mathrm{~s}^{-1}\right.$; $\mathrm{pH} 7.5,40^{\circ} \mathrm{C}$ ) for the same substrate. ${ }^{[23,49]}$ The rate-pH profile suggests an active species with a $\mathrm{p} K_{\mathrm{a}}$ value of about 8. A $\mathrm{p} K_{\mathrm{a}}$ value in this range can be attributed to a water or alcohol terminally bound to zinc ${ }^{[32]}$ and the following mechanisms are consistent with the kinetic $\mathrm{p} K_{\mathrm{a}}$ : (i) A terminal $\mathrm{Zn}-\mathrm{OH}$ group acts as a general base and deprotonates the $\mathrm{C} 2-\mathrm{OH}$ group of HPNP. Intramolecular attack of the deprotonated $\mathrm{C} 2-\mathrm{OH}$ group gives the cyclic phosphate ester and (ii) $\mathrm{Zn}$ coordinates to the $\mathrm{C} 2-\mathrm{OH}$ group and thus activates the nucleophile.

Again, reaction rates were measured in $\mathrm{D}_{2} \mathrm{O}$ to distinguish between nucleophile activation and a general base mechanism. $k_{\mathrm{H}} / k_{\mathrm{D}}$ was determined to be 2.64 indicating a general base mechanism with the formation of the $\mathrm{C} 2$ oxoanion in the rate-determining step. Potentiometric titration of 5 revealed a single deprotonation step so that $\left[\mathrm{Zn}_{2}\{\mathrm{bcmp}(-\mathrm{H})\}\left(\mu-\mathrm{H}_{2} \mathrm{O}\right)\right]^{3+}$ and $\left[\mathrm{Zn}_{2}\{\mathrm{bcmp}(-\mathrm{H})\}(\mu-\mathrm{OH})\right]^{2+}$ must be the only species present under the conditions of the kinetic study. There is no indication of any titratable terminally bound water molecule with a $\mathrm{p} K_{\mathrm{a}}$ value in the region of the kinetic $\mathrm{p} K_{\mathrm{a}}$. Thus, a mechanism that is consistent with the rate-pH profile would involve a shift of the $\mu$ $\mathrm{OH}$ group into a terminal position upon substrate coordination as shown in Scheme 3. Unfortunately, we cannnot

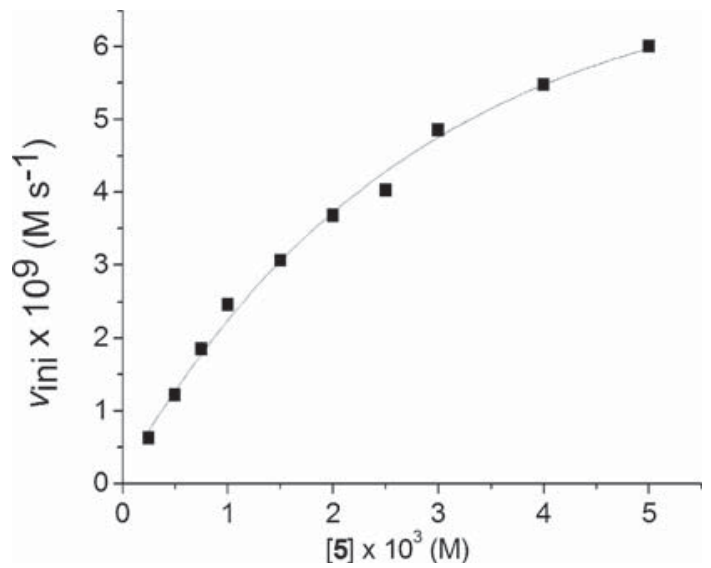

Figure 5. Dependence of the transesterification rate of HPNP $\left(5 \times 10^{-5} \mathrm{M}\right)$ on the concentration of 5 at $\mathrm{pH} 8.5$ (50 mM HEPES) and $40{ }^{\circ} \mathrm{C} ; I=0.1 \mathrm{M}\left(\mathrm{KNO}_{3}\right)$.

distinguish between a mono- and bidentate coordination mode of the phosphate diester, as all attempts to co-crystallise the $\mathrm{Zn}$ complex with a hydrolytically stable phosphate diester were unsuccessful. It should be noted that a shift of a bridging $\mathrm{OH}$ group to a terminal position or at least an elongation of one of the bridging bonds upon substrate coordination is discussed for dinuclear hydrolytically active Zn enzymes. ${ }^{[50]}$

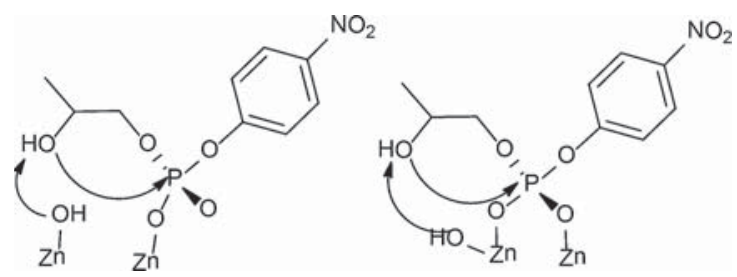

Scheme 3. Possible reaction mechanisms for the transesterification of HPNP by 5 .

To unambiguously identify the cleavage product, the reaction of 5 with HPNP was monitored by ${ }^{1} \mathrm{H}$ and ${ }^{31} \mathrm{P}$ NMR spectroscopy. The time-dependent ${ }^{31} \mathrm{P}$ NMR spectra of HPNP $\left(2.0 \times 10^{-2} \mathrm{M}\right)$ in the presence of 0.1 equiv. of 5 in $95 \% \mathrm{CD}_{3} \mathrm{OD} / 5 \% \mathrm{D}_{2} \mathrm{O}$ are shown in Figure $\mathrm{S} 8$. The ${ }^{31} \mathrm{P}$ NMR signal at $\delta=18.7 \mathrm{ppm}$ that increases with time confirms the formation of the 2,3-cyclic phosphate diester as the cleavage product. After $48 \mathrm{~h}, 1.4 \times 10^{-2} \mathrm{M}$ cyclophosphate has formed. Thus, the NMR experiments also suggest that $\mathbf{5}$ can act as a true catalyst.

\section{Cytotoxic Activity}

The cytotoxic properties of $\mathbf{5}$ were evaluated against a panel of human tumour cell lines containing examples of colorectal (HCT-15), pancreatic (BxPC3), cervical (A431), breast (MCF-7), lung (A549), and ovarian (2008) cancers. For comparison purposes, the cytotoxicity of cisplatin, the most widely used metal-based anticancer drug, was evaluated under the same experimental conditions. $\mathrm{IC}_{50}$ values, 
calculated from the dose vs. survival curves obtained after $72 \mathrm{~h}$ of drug treatment from the MTT test, are shown in Table 2 .

Table 2. Cytotoxic activity of $\mathbf{5}$ and cisplatin towards human cancer cell lines.

\begin{tabular}{lll}
\hline Cell lines & $\begin{array}{l}\mathrm{IC}_{50},[\mu \mathrm{M}] \pm \mathrm{SD}^{[\mathrm{a}]} \\
\text { cisplatin }\end{array}$ & {$\left[\mathrm{Zn}_{2}\{\mathrm{bcmp}(-\mathrm{H})\}(\mu-\mathrm{Cl})\right]\left(\mathrm{ClO}_{4}\right)_{2}$} \\
\hline HCT-15 & $11.32 \pm 1.51$ & $56.57 \pm 8.23$ \\
BxPC3 & $11.13 \pm 2.36$ & $12.52 \pm 2.43$ \\
A431 & $1.65 \pm 0.51$ & $42.41 \pm 4.06$ \\
MCF-7 & $7.60 \pm 0.21$ & $56.47 \pm 5.98$ \\
A549 & $9.98 \pm 2.86$ & $10.81 \pm 3.01$ \\
2008 & $2.22 \pm 1.03$ & $49.34 \pm 6.78$ \\
\hline
\end{tabular}

[a] Cells $\left(3-8 \times 10^{4} \mathrm{ml}^{-1}\right)$ were treated for $72 \mathrm{~h}$ with increasing concentrations of $\left[\mathrm{Zn}_{2}\{\mathrm{bcmp}(-\mathrm{H})\}(\mu-\mathrm{Cl})\right]\left(\mathrm{ClO}_{4}\right)_{2}$ or cisplatin. Cell viability was evaluated by means of MTT test. $\mathrm{IC}_{50}$ values were calculated by the dose-response curves by means of four parameter logistic model $(p<0.05)$; $\mathrm{SD}=$ standard deviation.

Although the cytotoxic activity was significantly lower than that of cisplatin against four of the tested tumor cell lines, the dimetallic $\mathrm{Zn}^{\mathrm{II}}$ complex retained a surprising in vitro antitumor activity against BxPC3 and A549 cancer cells. Notably, the $\mathrm{IC}_{50}$ values calculated for $\mathbf{5}$ in pancreatic BxPC3 and in "non small cells" lung cancer cells were comparable to those elicited by the reference metallo-drug cisplatin. These data highlight for $\mathbf{5}$ a particular activity against pancreatic and lung cancer cell histotypes.

\section{Conclusions}

$\left[\mathrm{Zn}_{2}\{\mathrm{bcmp}(-\mathrm{H})\}(\mu-\mathrm{OH})\right]^{2+}$ acts as a DNA binding and cleavage agent. It hydrolyzes the DNA model BDNPP by a mechanism involving nucleophilic attack by the bridging hydroxide. By contrast, a general base mechanism with a shift of the $\mu-\mathrm{OH}$ group into a terminal position is hypothesized for the cleavage of the RNA model HPNP.

Finally, the dinuclear zinc(II) complex exhibits in vitro antitumour activity against pancreatic and lung cancer cells.

\section{Experimental Section}

Materials and General Methods: Disodium $N, N^{\prime}, N^{\prime \prime}$-tritosyldiethylenetriamide, $\mathrm{Zn}\left(\mathrm{ClO}_{4}\right)_{2} \cdot 6 \mathrm{H}_{2} \mathrm{O}$, and $\mathrm{NaClO}_{4}$ were purchased from Aldrich and used as supplied. 1,2-bis(tosyloxy)ethane was purchased from TCI Europe and used as supplied. All the other chemicals and solvents were of analytical or spectroscopic grade, obtained from commercial sources and used without further purification. Deuterated solvents were obtained from Apollo Scientific. $N, N^{\prime}, N^{\prime \prime}$-Tris( $p$-tolylsulfonyl)-1,4,7-triazacyclononane [tacn$\left.(\mathrm{Ts})_{3}\right]{ }^{[51]}$ di-tert-butyl 1,4,7-triazacyclononane-1,4-dicarboxylate $\left[\operatorname{tacn}-(\mathrm{Boc})_{2}\right],{ }^{[52]}$ 2,6-bis(chloromethyl)-4-methylphenol, ${ }^{[53]}$ bis(2,4dinitrophenyl) phosphate (BDNPP) ${ }^{[54]}$ and the sodium salt of 2hydroxypropyl $p$-nitrophenyl phosphate (HPNP ${ }^{[55]}$ were prepared following the literature procedures. 1,4,7-Triazacyclononane (tacn) was synthesized according to a modified literature procedure (Supporting Information). ${ }^{[56]}$

${ }^{1} \mathrm{H}$ and ${ }^{31} \mathrm{P}$ NMR spectra were recorded on a Jeol EXC-400 spectrometer and referenced to TMS or the solvent residual peak as internal and $85 \% \mathrm{H}_{3} \mathrm{PO}_{4}$ as external reference. The $\mathrm{pD}$ values of $\mathrm{D}_{2} \mathrm{O}$ solutions were measured by use of a glass electrode and addition of a value of 0.4 to the $\mathrm{pH}$ meter reading. ${ }^{[57,58]}$ The $\mathrm{pD}$ values were adjusted using concentrated $\mathrm{DNO}_{3}$ and $\mathrm{NaOD}$ solutions. UV/Vis measurements were carried out on a Varian Cary 50 scan spectrophotometer coupled to a Grant thermostatted water circulation bath. Elemental analyses (carbon, hydrogen and nitrogen) were performed with a Perkin-Elmer 2400 series II analyzer. ESI Mass Spectra were recorded with Waters LCT Premier XE Spectrometer.

2,6-Bis(1,4,7-triazacyclonon-1-ylmethyl)-4-methylphenol (bcmp, 4): tacn-(Boc) $)_{2} \quad(3.83 \mathrm{~g}, 11.6 \mathrm{mmol})$ and triethylamine $(2.34 \mathrm{~g}$, $22.3 \mathrm{mmol}$ ) were dissolved in $30 \mathrm{~mL}$ of dry THF. 2,6-bis(chloromethyl)-4-methylphenol $(1.19 \mathrm{~g}, 5.8 \mathrm{mmol})$, dissolved in $30 \mathrm{~mL}$ of dry THF, was added dropwise at $0{ }^{\circ} \mathrm{C}$ over a period of $1 \mathrm{~h}$. A white solid formed immediately and the suspension was stirred for $20 \mathrm{~h}$ at $0{ }^{\circ} \mathrm{C}$. The white solid $\left(\mathrm{Et}_{3} \mathrm{NHCl}\right)$ was filtered off and the filtrate was evaporated to dryness by rotary evaporation. The resulting pale yellow powder was purified by column chromatography using petroleum ether/ethyl acetate $(5: 1)$ as eluent. $3.55 \mathrm{~g}$ of Boc protected bcmp (3) were obtained (4.5 mmol, 77\%). ${ }^{1} \mathrm{H} \mathrm{NMR}\left(\mathrm{CDCl}_{3}\right): \delta=$ $6.85\left(\mathrm{~s}, 2 \mathrm{H}, \mathrm{H}_{\mathrm{ar}}\right) ; 3.72\left(\mathrm{~s}, 4 \mathrm{H}, \mathrm{CH}_{2}\right) ; 3.46\left(\mathrm{~m}, 8 \mathrm{H}, \mathrm{CH}_{2}\right.$, tacn); $3.30\left(\mathrm{~m}, 8 \mathrm{H}, \mathrm{CH}_{2}\right.$, tacn); $2.69\left(\mathrm{~m}, 8 \mathrm{H}, \mathrm{CH}_{2}\right.$, tacn); $2.18(\mathrm{~s}, 3 \mathrm{H}$, $\left.\mathrm{CH}_{3}\right) ; 1.48\left[\mathrm{~s}, 18 \mathrm{H}, \mathrm{CH}_{3}(t \mathrm{Bu})\right] ; 1.45\left[\mathrm{~s}, 9 \mathrm{H}, \mathrm{CH}_{3}(t \mathrm{Bu})\right] ; 1.43[\mathrm{~s}, 9$ $\left.\mathrm{H}, \mathrm{CH}_{3}(t \mathrm{Bu})\right] .3$ was subsequently dissolved in $10 \mathrm{~mL}$ of $\mathrm{CH}_{2} \mathrm{Cl}_{2}$. A mixture of $\mathrm{CF}_{3} \mathrm{COOH} / \mathrm{CH}_{2} \mathrm{Cl}_{2}(27 \mathrm{~mL} / 27 \mathrm{~mL})$ was added dropwise at $0{ }^{\circ} \mathrm{C}$ and the mixture was stirred for $1 \mathrm{~h}$. The solvent was removed by rotary evaporation. The residue was treated with diethyl ether $(20 \mathrm{~mL})$ and dried again by rotary evaporation to remove residual trifluoroacetic acid. After repeating this procedure three times a yellow solid $\left(4 \cdot n \mathrm{CF}_{3} \mathrm{CO}_{2} \mathrm{H}\right)$ was obtained. ${ }^{1} \mathrm{H}$ NMR $\left(\mathrm{CD}_{3} \mathrm{OD}\right): \delta=7.03\left(\mathrm{~s}, 2 \mathrm{H}, \mathrm{H}_{\mathrm{ar}}\right) ; 3.94\left(\mathrm{~s}, 4 \mathrm{H}, \mathrm{CH}_{2}\right) ; 3.06(\mathrm{~m}, 8 \mathrm{H}$, $\mathrm{CH}_{2}$, tacn); $2.76\left(\mathrm{~m}, 8 \mathrm{H}, \mathrm{CH}_{2}\right.$, tacn); $2.64\left(\mathrm{~m}, 8 \mathrm{H}, \mathrm{CH}_{2}, \operatorname{tacn}\right)$; $2.20\left(\mathrm{~s}, 3 \mathrm{H}, \mathrm{CH}_{3}\right) \cdot \mathbf{4} \cdot n \mathrm{CF}_{3} \mathrm{CO}_{2} \mathrm{H}$ was dissolved in $50 \mathrm{~mL}$ of methanol and $200 \mathrm{~mL}$ of water. The solution was cooled to $0{ }^{\circ} \mathrm{C}$ and the $\mathrm{pH}$ was adjusted to 9 with $\mathrm{NaOH}$. The neutral ligand 4 was extracted with $3 \times 75 \mathrm{~mL}$ of $\mathrm{CHCl}_{3}$, washed with brine and dried with $\mathrm{Na}_{2} \mathrm{SO}_{4}$ which was filtered off. Evaporation of the filtrate to dryness gave 4 as a yellow oil, yield $1.57 \mathrm{~g}(46 \%) .{ }^{1} \mathrm{H}$ NMR $\left(\mathrm{CDCl}_{3}\right): \delta=6.80\left(\mathrm{~s}, 2 \mathrm{H}, \mathrm{H}_{\mathrm{ar}}\right) ; 3.72\left(\mathrm{~s}, 4 \mathrm{H}, \mathrm{CH}_{2}\right) ; 3.70$ (br. s, 1 $\mathrm{H}, \mathrm{OH}) ; 2.68\left(\mathrm{~m}, 24 \mathrm{H}, \mathrm{CH}_{2}\right.$, tacn); 2.19 (s, $\left.3 \mathrm{H}, \mathrm{CH}_{3}\right)$. ESI-MS: $m / z 391.31[\mathrm{M}+\mathrm{H}]^{+}$.

$\left[\mathbf{Z n}_{\mathbf{2}}\{\mathbf{b c m p}(-\mathbf{H})\}(\boldsymbol{\mu}-\mathbf{C l})\right]\left(\mathbf{C l O}_{\mathbf{4}}\right)_{\mathbf{2}}(\mathbf{5})$ : The $\mathrm{Zn}$ complex was obtained by mixing an aqueous solution $(10 \mathrm{~mL})$ of $\mathrm{Zn}\left(\mathrm{ClO}_{4}\right)_{2} \cdot 6 \mathrm{H}_{2} \mathrm{O}$ (400 mg, $1.07 \mathrm{mmol}$ ) and a methanolic solution $(5 \mathrm{~mL})$ of bcmp ( $209 \mathrm{mg}, 0.54 \mathrm{mmol}$ ) and adjusting the $\mathrm{pH}$ to 6.2 with $\mathrm{NaOH}$. The transparent, clear solution was evaporated on a rotavapor. The residue was dissolved in $12 \mathrm{~mL}$ of methanol and filtered. Slow diffusion of diethyl ether into the alcoholic solution afforded colourless crystals of formula $\left[\mathrm{Zn}_{2}\{\mathrm{bcmp}(-\mathrm{H})(\mu-\mathrm{Cl})]\left(\mathrm{ClO}_{4}\right)_{2}\right.$, yield $310 \mathrm{mg}$ $(0.42 \mathrm{mmol}, 73 \%)$. Anal. Calcd. (\%) for $\mathrm{C}_{21} \mathrm{H}_{37} \mathrm{Cl}_{3} \mathrm{~N}_{6} \mathrm{O}_{9} \mathrm{Zn}_{2}$ : C, 33.42; H, 4.95; N, 11.13; found $\mathrm{C}, 33.54, \mathrm{H}, 4.90 ; \mathrm{N}, 10.86 .{ }^{1} \mathrm{H}$ NMR ( $\left.\mathrm{D}_{2} \mathrm{O}, \mathrm{pD} 6.8\right): \delta=6.87\left(\mathrm{~s}, 2 \mathrm{H}, \mathrm{H}_{\mathrm{ar}}\right) ; 3.78\left(\mathrm{~s}, 4 \mathrm{H}, \mathrm{CH}_{2}\right)$; 2.89 (br. m, $6 \mathrm{H}, \mathrm{CH}_{2}$, tacn); 2.60 (br. m, $12 \mathrm{H}, \mathrm{CH}_{2}$, tacn); 2.50 (m, br., $6 \mathrm{H}, \mathrm{CH}_{2}$, tacn); 2.04 (s, $3 \mathrm{H}, \mathrm{CH}_{3}$ ). ESI-MS: $m / z 633.11$ $\left[\left[\mathrm{Zn}_{2}\{\mathrm{bcmp}(-\mathrm{H})\}(\mu-\mathrm{OH})\right]\left(\mathrm{ClO}_{4}\right)\right]^{+}$.

Crystals of $\mathbf{5} \cdot \mathbf{H}_{2} \mathrm{O}$ suitable for X-ray analysis were obtained by slow evaporation (4 weeks) of an aqueous solution $(5 \mathrm{~mL})$ of $20 \mathrm{mg}$ of the complex. The presence of the chlorido ligand is most likely due to the contamination of the ligand with chloride during the workup. Washing the neutral ligand with brine led to batches containing sizeable amounts of the hydrochloride. 
Caution! Although no problems were encountered in this work, transition metal perchlorate complexes are potentially explosive and should be handled with proper precautions.

Potentiometric Titration: An aqueous solution of $5(1 \mathrm{~mm}, 100 \mathrm{~mL})$ was titrated with a standardized $0.1 \mathrm{M} \mathrm{NaOH}$ solution at $25^{\circ} \mathrm{C}$. The ionic strength was maintained at $0.1 \mathrm{M}$ with $\mathrm{KNO}_{3}$. $\mathrm{pH}$ values were measured with a Jenway $3510 \mathrm{pH}$ meter fitted with a Refex Sensor Ltd. EC-1910-11 glass electrode. The program HYPERQUAD was used to calculate the deprotonation constant from the titration data. ${ }^{[59]}$

UV Kinetic Measurements: The hydrolysis rates of BDNPP and HPNP were measured by monitoring the increase in the visible absorbance at $400 \mathrm{~nm}$ due to the release of the 2,4-dinitrophenolate and 4-nitrophenolate anions. Rate constants were obtained by the initial rate method $(<5 \%$ conversion). Concentrations of 2,4 -dinitrophenolate and 4-nitrophenolate were calculated from the extinction coefficients (12100 and $18700 \mathrm{~m}^{-1} \mathrm{~cm}^{-1}$ for 2,4-dinitrophenolate and 4-nitrophenolate, respectively). Concentrations were corrected for the degree of ionization of 2,4-dinitrophenol and 4-nitrophenol at the respective $\mathrm{pH}$ value using $\mathrm{p} K_{\mathrm{a}}$ (2,4-dinitrophenol) $=$ $4.0^{[60]}$ and $\mathrm{p} K_{\mathrm{a}}$ (4-nitrophenol) $=7.15 .^{\left[{ }^{[61]}\right.} \mathrm{In}$ a typical experiment $15 \mu \mathrm{L}$ of a freshly prepared BDNPP or HPNP stock solution $(5 \mathrm{~mm}$ in DMSO and $\mathrm{H}_{2} \mathrm{O}$, respectively) were added to a solution of the metal complex $(1.5 \mathrm{~mL}, 0.25-5 \mathrm{~mm})$ at $40^{\circ} \mathrm{C}$. The metal complex solutions were buffered with 50 mM PIPBS (pH 3.5-5), MES (pH 5-6.7), HEPES ( $\mathrm{pH} 6.8-8.5$ ) and CHES ( $\mathrm{pH} 8.5-11.0$ ). The ionic strength was maintained at $0.1 \mathrm{M}$ with $\mathrm{KNO}_{3}$. Cleavage rates for BDNPP and HPNP have been corrected for the spontaneous hydrolysis of the substrates. ${ }^{[54]}$ The kinetic $\mathrm{p} K_{\mathrm{a}}$ values were determined by fitting the data to

$k_{\mathrm{obs}}=\left(k_{\mathrm{H} 2 \mathrm{O}}\left[\mathrm{H}^{+}\right]+k_{\mathrm{OH}} K_{\mathrm{a}}\right) /\left(K_{\mathrm{a}}+\left[\mathrm{H}^{+}\right]\right)$.

To determine the solvent deuterium isotope effect, analogous kinetic experiments were performed in $99.9 \% \mathrm{D}_{2} \mathrm{O}$. The correction $\mathrm{pD}=\mathrm{pH}_{\text {measured }}+0.4$ was applied to the $\mathrm{pH}$ meter readings. ${ }^{[57,58]}$ Kinetic runs were run in duplicate to give a reproducibility of $\pm 15 \%$

NMR Kinetic Measurements: The transesterification rate of HPNP in methanol was measured by monitoring the increase of the intensities of the ${ }^{31} \mathrm{P}$ and ${ }^{1} \mathrm{H}$ NMR peaks of the cleavage products with respect to the HPNP signals. The experiments were conducted in $\mathrm{CD}_{3} \mathrm{OD} / \mathrm{D}_{2} \mathrm{O}$ (95:5). The substrate concentration was $20 \mathrm{~mm}$. The ratio between HPNP and the Zn complex was 10:1 in all experiments.

X-ray Analysis: Crystal data of $5 \cdot \mathrm{H}_{2} \mathrm{O}$ were collected at room temperature on an Oxford Diffraction Xcalibur CCD diffractometer using graphite-monochromated Mo- $K_{\alpha}$ radiation $(\lambda=$ $0.71069 \AA$ ).${ }^{[62]}$ The structure was solved by direct methods and subsequent Fourier syntheses and refined by full-matrix least-squares on $F^{2}$ using SHELXS-97, SHELXL-97 ${ }^{[63]}$ and Oscail. ${ }^{[64]}$ The scattering factors were those given in the SHELXL program. Hydrogen atoms except those of the water molecule of crystallization were generated geometrically and refined as riding atoms with isotropic displacement factors equivalent to 1.2 times those of the atom to which they were attached ( 1.5 for methyl groups). The water molecule of crystallization is disordered over two positions having site occupancy factors of 0.5 . Each of the disordered water molecules is part of a hexagon of symmetry-related H-bonded water molecules. Graphics were produced with ORTEX. ${ }^{[65]}$ Crystallographic data and details of refinement are reported in Table 3.
Table 3. Crystallographic data for compound $\mathbf{5} \cdot \mathbf{H}_{2} \mathbf{O}$

\begin{tabular}{ll}
\hline Formula & $\mathrm{C}_{21} \mathrm{H}_{39} \mathrm{Cl}_{3} \mathrm{~N}_{6} \mathrm{O}_{10} \mathrm{Zn}_{2}$ \\
$M_{\mathrm{r}}$ & 772.67 \\
Crystal colour and habit & colourless block \\
Crystal size & $0.30 \times 0.25 \times 0.22$ \\
Crystal system & trigonal \\
Space group & $R \overline{3}$ \\
$a / \AA$ & $35.407(1)$ \\
$b / \AA$ & $35.407(1)$ \\
$c / \AA$ & $12.9018(4)$ \\
$V / \AA^{3}$ & $14007.3(9)$ \\
$\mathrm{Z}$ & 18 \\
$D_{\text {calc }} / \mathrm{gcm}^{-3}$ & 1.649 \\
$\mu\left(\right.$ Mo- $\left.K_{\alpha}\right) / \mathrm{mm}^{-1}$ & 1.858 \\
$F(000)$ & 7164 \\
$2 \theta$ range $/^{\circ}$ & $6.1-50.7$ \\
Measured reflections & 9865 \\
Unique reflections $\left(R_{\text {int }}\right)$ & $5707(2.3 \%)$ \\
Observed reflections & $4552[I>2 \sigma(I)]$ \\
Parameters & 379 \\
Final $R_{1}, w R_{2}[I>2 \sigma(I)]^{[a]}$ & $3.8 \%, 10.2 \%$ \\
Final $R_{1}, w R_{2}\left(\right.$ all data ${ }^{[\mathrm{a}]}$ & $5.5 \%, 11.2 \%$ \\
Goodness-of-fit & 1.037 \\
(observed reflections) $^{\text {obser }}$ &
\end{tabular}

[a] $R_{1}=\Sigma|| F_{\mathrm{o}}|-| F_{\mathrm{c}}|/ \Sigma| F_{\mathrm{o}} \mid ; w R_{2}=\left[\Sigma w\left(F_{\mathrm{o}}{ }^{2}-F_{\mathrm{c}}\right)^{2} / \Sigma w\left(F_{\mathrm{o}}{ }^{2}\right)^{2}\right] 1 / 2 ; w^{-1}$ $=\sigma^{2}\left(F_{\mathrm{o}}{ }^{2}\right)+(a P)^{2} ; P=\left(F_{\mathrm{o}}{ }^{2}+2 F_{\mathrm{c}}{ }^{2}\right) / 3$.

CCDC-920702 contains the supplementary crystallographic data for this paper. These data can be obtained free of charge from The Cambridge Crystallographic Data Centre via www.ccdc.cam.ac.uk/ data_request/cif.

DNA Interaction: Fluorescence Quenching Experiments: The influence of the addition of increasing concentrations of compound 5 to the DNA-ethidium bromide (EB) complex solution composed of $10 \mu \mathrm{M}$ CT-DNA $(8.0-15 \mathrm{kbp})$ and $0.33 \mu \mathrm{M}$ EB in Tris buffer solution, has been obtained by recording the variation of the fluorescence emission spectra. The fluorescence spectrum of the solution was obtained by exciting at $520 \mathrm{~nm}$ and measuring the emission spectrum at $587 \mathrm{~nm}$. The quenching efficiency for $\mathbf{5}$ was evaluated according to the classical Stern-Volmer equation:

$F_{0} / F=1+K_{\mathrm{SV}} r$

where $F_{0}$ is the emission intensity in the absence of quencher, $F$ is the emission intensity in the presence of quencher, $K_{\mathrm{SV}}$ is the SternVolmer constant, and $\mathrm{r}$ is the concentration ratio of the complex to DNA. $K_{\mathrm{SV}}$ constant was determined from the slope of the plot of $F_{0} / F$ vs. $r$.

pUC19 DNA Cleavage Activity: The DNA cleavage ability of compound $\mathbf{5}$ was evaluated by agarose gel electrophoresis. DNA plasmid pUC19 (2686 bp) at concentration $1 \mu \mathrm{g} / \mu \mathrm{L}$ was incubated with increasing concentration (range $5-50 \mu \mathrm{M})$ of $\mathbf{5}$ in Tris buffer $(50 \mathrm{~mm}$ Tris, $18 \mathrm{~mm} \mathrm{NaCl}, \mathrm{pH} 8.2$ ) at $37^{\circ} \mathrm{C}$ for $3 \mathrm{~h}$ in the dark. The reaction was quenched by the addition of $3 \mu \mathrm{L}$ of loading buffer $(0.25 \%$ bromophenol blue and $30 \%$ glycerol), and samples were loaded onto a $1 \%$ agarose gel in TBE buffer $(89 \mathrm{~mm}$ Tris, $89 \mathrm{~mm}$ boric acid, 2 mm EDTA, pH 8.2). The gels were subjected to electrophoresis for $4 \mathrm{~h}$ at $50 \mathrm{~V}$, followed by staining with $0.5 \mu \mathrm{g} / \mathrm{mL} \mathrm{EB}$ overnight. Gel bands were visualized using a UV transilluminator and photographed using an Olympus ${ }^{\circledR}$ digital camera.

Experiments with Cultured Human Cells: Compound $\mathbf{5}$ was dissolved in DMSO just before the experiment, and a calculated amount of drug solution was added to the cell growth medium to a final solvent concentration of $0.5 \%$, which had no detectable effect on cell killing. Cisplatin was dissolved in $0.9 \%$ sodium chloride 
solution. MTT [3-(4,5-dimethylthiazol-2-yl)-2,5-diphenyltetrazolium bromide] and cisplatin were obtained from Sigma Chemical Co, St. Louis, USA.

Cell Cultures: Human lung (A549), breast (MCF-7), colon (HCT15), and pancreatic (BxPC3) carcinoma cell lines were obtained from American Type Culture Collection (ATCC, Rockville, MD). Human ovarian cancer cell lines 2008 were kindly provided by Prof. G. Marverti (Dept. of Biomedical Science of Modena University, Italy). Human cervical carcinoma cells A431 were kindly provided by Prof. F. Zunino (Division of Experimental Oncology B, Istituto Nazionale dei Tumori, Milan, Italy). LoVo human colon-carcinoma cell line were kindly provided by Prof. F. Majone (Department of Biology of Padova University, Italy). Cell lines were maintained in the logarithmic phase at $37^{\circ} \mathrm{C}$ in a $5 \%$ carbon dioxide atmosphere using the following culture media containing $10 \%$ fetal calf serum (Euroclone, Milan, Italy), antibiotics (50 units $/ \mathrm{mL}$ penicillin and $50 \mu \mathrm{g} / \mathrm{mL}$ streptomycin), and $2 \mathrm{~mm}$ L-glutamine: (i) RPMI-1640 medium (Euroclone) for MCF-7, HCT-15, A431, 2008 and BxPC3 cells; (ii) F-12 HAM'S (Sigma Chemical Co.) for LoVo and A549 cells.

MTT Assay: The growth inhibitory effect toward tumor cells was evaluated by means of MTT assay. ${ }^{[66]}$ Briefly, $(3-8) \times 10^{3}$ cells/well, dependent upon the growth characteristics of the cell line, were seeded in 96-well microplates in growth medium $(100 \mu \mathrm{L})$. After $24 \mathrm{~h}$, the medium was removed and replaced with fresh media containing the compound to be studied at the appropriate concentration. Triplicate cultures were established for each treatment. After $72 \mathrm{~h}$, each well was treated with $10 \mu \mathrm{L}$ of a $5 \mathrm{mg} / \mathrm{mL}$ MTT saline solution, and following $5 \mathrm{~h}$ of incubation, $100 \mu \mathrm{L}$ of a sodium dodecylsulfate (SDS) solution in $\mathrm{HCl} 0.01 \mathrm{~m}$ was added. After an overnight incubation, cell growth inhibition was detected by measuring the absorbance of each well at $570 \mathrm{~nm}$ using a Bio-Rad 680 microplate reader. Mean absorbance for each drug dose was expressed as a percentage of the control untreated well absorbance and plotted vs. drug concentration. $\mathrm{IC}_{50}$ values, the drug concentrations that reduce the mean absorbance at $570 \mathrm{~nm}$ to $50 \%$ of those in the untreated control wells, were calculated by four parameter logistic (4-PL) model.

Supporting Information (see footnote on the first page of this article): Synthetic procedure for compound $1,{ }^{1} \mathrm{H}$ and ${ }^{31} \mathrm{P}$ NMR spectra.

\section{Acknowledgments}

Financial support from the European Commission and Science Foundation Ireland (Marie Curie FP7-IEF, grant to D. M. and Stokes Lectureship to A. E., grant number 07/SK/B1225b) are gratefully acknowledged. The authors thank Ms. Jolanta Karpinska for the collection of the X-ray data. Prof. Michael J. Hynes is thanked for the calculation of the deprotonation constant from the titration data.

[1] a) B. Rosenberg, L. Van Camp, T. Krigas, Nature 1965, 205, 698-699; b) B. Rosenberg, L. Van Camp, J. E. Trosko, V. H. Mansour, Nature 1969, 222, 385-386; c) A. Horwich, J. Shipley, R. Huddart, Lancet 2006, 367, 754-765; d) L. Kelland, Nat. Rev. Cancer 2007, 7, 573-584; e) D. Wang, S. J. Lippard, Nat. Rev. Drug Discovery 2005, 4, 307-320.

[2] M. A. Fuertes, C. Alonso, J. M. Perez, Chem. Rev. 2003, 103, $645-662$.

[3] a) C. Metcalfe, J. A. Thomas, Chem. Soc. Rev. 2003, 32, 215224; b) A. Silvestri, G. Barone, G. Ruisi, M. T. Lo Giudice, S.
Tumminello, J. Inorg. Biochem. 2004, 98, 589-594; c) M. Navarro, E. J. Cisneros-Fajardo, A. Sierralta, M. Fernandez-Mestre, P. Silva, D. Arrieche, E. Marchan, J. Biol. Inorg. Chem. 2003, 8, 401-408.

[4] a) H. H. Thorp, Chem. Biol. 1998, 5, R125-R127; b) H. Vahrenkamp, Dalton Trans. 2007, 4751-4759; c) A. I. Anzellotti, N. P. Farrell, Chem. Soc. Rev. 2008, 37, 1629-1651.

[5] a) P. U. Maheswari, S. Barends, S. O. Yaman, P. Hoog, H. Casellas, S. J. Teat, C. Massera, M. Lutz, A. L. Spek, G. P. vanWezel, P. Gamez, J. Reedijk, Chem. Eur. J. 2007, 13, 52135222; b) J. H. Li, J. T. Wang, Z. W. Mao, L. N. Ji, Inorg. Chem. Commun. 2008, 11, 865-868; c) C. Bazzicalupi, A. Bencini, A. Bianchi, T. Biver, A. Boggioni, S. Bonacchi, A. Danesi, C. Giorgi, P. Gratteri, A. M. Ingrain, F. Secco, C. Sissi, B. Valtancoli, M. Venturini, Chem. Eur. J. 2008, 14, 184-196; d) J. Wang, Z.-Y. Yang, X.-Y. Yi, B.-D. Wang, J. Photochem. Photobiol. A: Chem. 2009, 201, 183-190.

[6] Q. Huang, Z. Pan, P. Wang, Z. Chen, X. Zhang, H. Xu, Bioorg. Med. Chem. Lett. 2006, 16, 3030-3033.

[7] a) A. Nakayama, M. Hiromura, Y. Adachi, H. Sakurai, J. Biol. Inorg. Chem. 2008, 13, 675-684; b) H. Sakurai, Y. Yoshikawa, H. Yasui, Chem. Soc. Rev. 2008, 37, 2383-2392.

[8] a) Z. H. Chohan, M. Arif, M. Sarfraz, Appl. Organomet. Chem. 2007, 21, 294-302; b) V. P. Singh, A. Katiyar, J. Coord. Chem. 2008, 61, 3200-32012; c) M. T. Kaczmarek, R. Jastrza, E. Hołderna-Kedzia, W. Radecka-Paryzek, Inorg. Chim. Acta 2009 , $362,3127-3133$

[9] a) D. Miyamoto, N. Endo, N. Oku, Y. Arima, T. Suzuki, Y. Suzuki, Biol. Pharm. Bull. 1998, 21, 1258-1262; b) M. Belicchi Ferrari, F. Bisceglie, G. Pelosia, P. Tarasconia, R. Albertini, S. Pinelli, J. Inorg. Biochem. 2001, 87, 137-147; c) H. Beraldo, D. Gambinob, Mini-Rev. Med. Chem. 2004, 4, 31-39; d) M. C. Rodrıguez-Arguelles, M. Belicchi Ferrari, F. Bisceglie, C. Pelizzi, G. Pelosi, S. Pinelli, M. Sassi, J. Inorg. Biochem. 2004, 98 , 313-321: e) H. Zhang, C. S. Liu, X. H. Bu, M. Yang, J. Inorg. Biochem. 2005, 99, 1119-1125; f) Z. Travnicek, V. Krystof, M. Sipl, J. Inorg. Biochem. 2006, 100, 214-225; g) X. Sheng, X. Guo, X. M. Lu, G. Y. Lu, Y. Shao, F. Liu, Q. Xu, Bioconjugate Chem. 2008, 19, 490-498; h) J. Tan, B. Wang, L. Zhu, Bioorg. Med. Chem. 2009, 17, 614-620; i) Q. Jiang, J. Zhu, Y. Zhang, N. Xiao, Z. Guo, BioMetals 2009, 22, 297-305; j) C. Y. Gao, X. Qiao, Z. Y. Ma, Z. Wang, J. Lu, J. L. Tian, J. Y. Xub, S. P. Yan, Dalton Trans. 2012, 41, 12220-12232.

[10] A. Lahm, A. Volbeda, D. Suck, J. Mol. Biol. 1990, 215, 207210.

[11] E. E. Kim, H. W. Wyckoff, J. Mol. Biol. 1991, 218, 449-464.

[12] E. Hough, L. K. Hansen, B. Birknes, K. Jynge, S. Hansen, A. Hordvik, C. Little, E. Dodson, Z. Derewenda, Nature 1989, $338,357-360$.

[13] N. Sträter, W. N. Lipscomb, Biochemistry 1995, 34, 14792 14800.

[14] D. E. Wilcox, Chem. Rev. 1996, 96, 2435-2458, and references cited therein.

[15] E. Kimura, Curr. Opin. Chem. Biol. 2000, 4, 207-213.

[16] F. Mancin, P. Scrimin, P. Tecilla, U. Tonellato, Chem. Commun. 2005, 2540-2548, and references cited therein.

[17] L. R. Gahan, S. J. Smith, A. Neves, G. Schenk, Eur. J. Inorg. Chem. 2009, 2745-2758.

[18] O. Iranzo, T. Elmer, J. P. Richard, J. R. Morrow, Inorg. Chem. 2003, 42, 7737-7746.

[19] C. Vichard, T. A. Kaden, Inorg. Chim. Acta 2002, 337, 173180.

[20] M. Arca, A. Bencini, E. Berni, C. Caltagirone, F. A. Devillanova, F. Isaia, A. Garau, C. Giorgi, V. Lippolis, A. Perra, L. Te, B. Valtancoli, Inorg. Chem. 2003, 42, 6929-6939.

[21] X. Sheng, X. Guo, X. M. Lu, G. Y. Lu, Y. Shao, F. Liu, Q. Xu, Bioconjugate Chem. 2008, 19, 490-498.

[22] O. Iranzo, A. Y. Kovalevsky, J. R. Morrow, J. P. Richard, J. Am. Chem. Soc. 2003, 125, 1988-1993. 
[23] a) C. Sissi, P. Rossi, F. Felluga, F. Formaggio, M. Palumbo, P. Tecilla, C. Toniolo, P. Scrimin, J. Am. Chem. Soc. 2001, 123, 3169-3170; b) M. Diez-Castellnou, F. Mancin, P. Scrimin, $J$. Am. Chem. Soc. 2014, 136, 1158-1161.

[24] M. Kodama, E. Kimura, J. Chem. Soc., Dalton Trans. 1978, 1081-1085.

[25] H. S. Chang, H. Diril, M. J. Nilges, X. Zhang, J. A. Potenza, H. J. Schugar, D. N. Hendrickson, S. S. Isied, J. Am. Chem. Soc. 1988, 110, 625-627.

[26] A. W. Addison, T. N. Rao, J. Reedijk, J. van Rijn, G. C. Verschoor, J. Chem. Soc., Dalton Trans. 1984, 1349-1356.

[27] G. Schwarzenbach, P. Moser, Helv. Chim. Acta 1953, 36, 581597.

[28] L. Sacconi, P. Paoletti, M. J. Ciampolini, Chem. Soc. 1961, 5115-5120.

[29] C. Y. Ng, R. J. Motekaitis, A. E. Martell, Inorg. Chem. 1979, $18,2982-2986$.

[30] X. Sheng, X. Guo, X.-M. Lu, Y. Shao, F. Liu, Q. Xu, Bioconjugate Chem. 2008, 19, 490-498.

[31] M. Yashiro, R. Kawahara, J. Biol. Inorg. Chem. 2004, 9, 914 921.

[32] C. Bazzicalupi, A. Bencini, E. Berni, A. Bianchi, V. Fedi, V. Fusi, C. Giorgi, P. Paoletti, B. Valtancoli, Inorg. Chem. 1999, $38,4115-4122$.

[33] C. He, S. J. Lippard, J. Am. Chem. Soc. 2000, 122, 184-185.

[34] A. M. Barrios, S. J. Lippard, J. Am. Chem. Soc. 1999, 121, $11751-11757$.

[35] M. Lee, A. L. Rhodes, M. D. Wyatt, S. Forrow, J. A. Hartley, Biochemistry 1993, 32, 4237-4245.

[36] J. Weston, Chem. Rev. 2005, 105, 2151-2174.

[37] B. Das, H. Daver, M. Pyrkosz-Bulska, E. Persch, S. K. Barman, R. Mukherjee, E. Gumienna-Kontecka, M. Jarenmark, F. Himo, E. Nordlander, J. Inorg. Biochem. 2014, 132, 6-17.

[38] V. Gold, Advances in Physical Organic Chemistry, Academic Press, New York, 1967.

[39] A. Neves, M. Lanznaster, A. J. Bortoluzzi, R. A. Peralta, A. Casellato, E. E. Castellano, P. Herrald, M. J. Riley, G. Schenk, J. Am. Chem. Soc. 2007, 129, 7486-7487.

[40] M. Lanznaster, A. Neves, A. J. Bortoluzzi, V. V. E. Aires, B. Szpoganicz, H. Terenzi, P. Cardoso Severino, J. M. Fuller, S. C. Drew, L. R. Gahan, G. R. Hanson, M. J. Riley, G. Schenk, J. Biol. Inorg. Chem. 2005, 10, 319-332.

[41] C. Piovezan, R. Jovito, A. J. Bortoluzzi, H. Terenzi, F. L. Fischer, P. C. Severino, C. T. Pich, G. G. Azzolini, R. A. Peralta, L. M. Rossi, A. Neves, Inorg. Chem. 2010, 49, 2580-2582.

[42] P. Karsten, A. Neves, A. J. Bortoluzzi, M. Lanznaster, V. Drago, Inorg. Chem. 2002, 41, 4624-4626.

[43] N. A. Rey, A. Neves, A. J. Bortuluzzi, C. T. Pich, H. Terenzi, Inorg. Chem. 2007, 46, 348-350.

[44] N. A. Rey, A. Neves, W. B. De Almeida, H. F. Dos Santos, A. S. Costa, Int. J. Quantum Chem. 2010, 110, 1432-1442.
[45] N. H. Williams, B. Takasaki, M. Wall, J. Chin, Acc. Chem. Res. 1999, 32, 485-493.

[46] P. Rossi, F. Felluga, P. Tecilla, F. Formaggio, M. Crisma, C. Toniolo, P. Scrimin, Biopolymers 2000, 55, 496-501.

[47] K. Selmeczi, C. Michel, A. Milet, I. Gautier-Luneau, C. Philouze, J. L. Pierre, D. Schnieders, A. Rompel, C. Belle, Chem. Eur. J. 2007, 13, 9093-9106.

[48] J. R. Morrow, O. Iranzo, Curr. Opin. Chem. Biol. 2004, 8, 192200.

[49] G. Feng, D. Natale, R. Prabaharan, J. C. Mareque-Rivas, N. H. Williams, Angew. Chem. Int. Ed. 2006, 45, 7056-7059; Angew. Chem. 2006, 118, 7214 .

[50] a) B. Bennett, R. C. Holz, J. Am. Chem. Soc. 1997, 119, 19231933; b) X. Wang, R. Y. N. Ho, A. K. Whiting, L. Que Jr., J. Am. Chem. Soc. 1999, 121, 9235-9236; c) Y. S. Yang, J. M. McCormick, E. I. Solomon, J. Am. Chem. Soc. 1997, 119, 11832-11842; d) F. Ely, K. S. Hadler, N. Mitic, L. R. Gahan, D. L. Ollis, N. M. Plugis, M. T. Russo, J. A. Larrabee, G. Schenk, J. Biol. Inorg. Chem. 2011, 16, 777-787.

[51] J. Hasserodt, United States Patent Application 20070218010A1.

[52] S. Kimura, E. Bill, E. Bothe, T. Weyhermuller, K. Wieghard, J. Am. Chem. Soc. 2001, 123, 6025-6039.

[53] P. Chirakul, P. D. Hampton, Z. Bencze, J. Org. Chem. 2000, 65, 8297-8300.

[54] C. A. Bunton, S. J. Farber, J. Org. Chem. 1969, 34, 767-772.

[55] D. M. Brown, D. A. Usher, J. Chem. Soc. 1965, 6558-6564.

[56] V. Stavila, M. Allali, L. Canaple, Y. Stortz, C. Franc, P. Maurin, O. Beuf, O. Dufay, J. Samarut, M. Janier, J. Hasserodt, New J. Chem. 2008, 32, 428-435.

[57] P. K. Glasoe, F. A. Long, J. Phys. Chem. 1960, 64, 188-190.

[58] K. Mikkelse, S. O. Nielsen, J. Phys. Chem. 1960, 64, 632-637.

[59] P. Gans, A. Sabatini, A. Vacca, Talanta 1996, 43, 1739-1753.

[60] A. E. Martell, R. M. Smith, Critical Stability Constants, Plenum press, New York, 1977.

[61] S. Espinosa, E. Bosch, M. Roses, J. Chromatogr. A 2002, 964, 55-66.

[62] Crys AlisPro, Oxford Diffraction Ltd., version 1.171.33.31 (release 08-01-2009, CrysAlis171.NET).

[63] a) G. M. Sheldrick, SHELXS-97, Program for Crystal Structure Solution, University of Göttingen, Germany, 1997; b) G. M. Sheldrick, SHELXL-97, Program for Crystal Structure Refinement, University of Göttingen, Germany, 1997; c) G. M. Sheldrick, SHELXTL-PLUS (VMS), Siemens Analytical Xray Instruments, Inc., Madison, WI, 1990.

[64] P. McArdle, K. Gilligan, D. Cunningham, R. Dark, M. Mahon, CrystEng Comm 2004, 6, 303-309.

[65] PC Windows ${ }^{\circledR}$ version: P. McArdle, J. Appl. Crystallogr. 1995, $28,65-65$.

[66] M. C. Alley, D. A. Scudiero, A. Monks, M. L. Hursey, M. J. Czerwinski, D. L. Fine, B. J. Abbott, J. G. Mayo, R. H. Shoemaker, M. R. Boyd, Cancer Res. 1988, 48, 589-601.

Received: April 15, 2014 Published Online: June 24, 2014 